TAPROBANICA, ISSN 1800-427X. December, 2013. Vol. 05, No. 02: pp. 148-150, 2 pls. (c) Taprobanica Private Limited, 146, Kendalanda, Homagama, Sri Lanka.

http://www.sljol.info/index.php/tapro

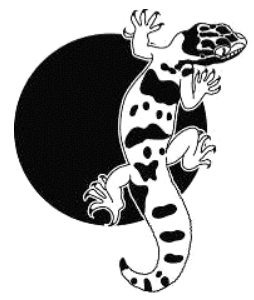

\section{Syzygium rama-varma (Myrtaceae) from southern Western Ghats, India}

Based on the collections from Travancore, India (Chemunji hills, Muthukuzhivayal Bourdillon s.n.), Bourdillon (1904) described and illustrated Eugenia rama-varma Bourd. (Myrtaceae, as "Rama Varma", "named after H.H. [Mulam Thirunal Rama Varma] the Maharaja of Travancore", [correctable errors under Arts. 60.9; McNeill et al., 2006]), with a comment: "a very handsome evergreen tree found at high elevation above $4000 \mathrm{ft}$ ". Gamble (1919) transferred it to Jambosa, as J. ramavarma (Bourd.) Gamble. Later Chithra (in Nair \& Henry, 1983) transferred it to Syzygium and made the combination S. rama-varma (Bourd.) Chithra (as "rama-varmae").

Bourdillon's paper most certainly was published in April 1904, the date on the heading of the issue, yet he refers to Brandis' Indian Trees p. 318, which was published on or just before 22 November 1906 (Stafleu \& Cowan 1976, citing a letter from Brandis giving the date). Brandis attributed the name and description to "Bourdillon mss." with a lengthier dedication "who wisely insists on a good management of his forests in the interest of future generations".

Bourdillon did not designate a type, and subsequent authors did not select one from the four known syntypes at K, FRC and TBGT nor did any author declare the published figure as the type. There exists a morphological similarity between $S$. rama-varma and $S$. munronii (Walp.) Chandrab., and this also prompted us to designate a type for the former to avoid any confusion in the future. The sheet in FRC, collected by Bourdillon in the Chemunji hills, on 4 April 1895, bears the collection no. 563. The two sheets in TBGT bear the numbers 563 ( $4^{\text {th }}$ April, 1895) and 3428 (s.d.), are from the Chemunji hills. The specimen in $\mathrm{K}$ (see http://apps.kew.org; s.d., s.n., Barcode No. K000793892!) from the Chemunji hills, Muthukuzhivayal, was annotated and used by Bourdillon for the description of Eugenia rama-varma as is exemplified by the diagnosis and illustration in the protologue. Thus, the Kew specimen is here designated as the lectotype.

Ahmedulla \& Nayar (1986) categorized Syzygium rama-varma as 'rare'. However, Nayar (1996) treated it as 'critical'. Later, Ramesh \& Pascal (1997) cited a single collection from the Anamalai hills of Tamil Nadu as another locality. Subsequently, Gopalan \& Henry (2000) cited a collection of A. N. Henry from Muthukuzhivayal [coll. No.60716 (MH!)], now in Tamil Nadu state and commented that they could locate only a few mature individuals in an isolated pocket. While working on the 'Flora of Agasthyamala', including Chemunji hills region, Mohanan \& Sivadasan (2002) could not locate the species, but included it in their flora on the basis of the earlier collections housed at TBGT made by Bourdillon from Chemunji hills and did not study the A. N. Henry collection. Based on these data, the IUCN (2012) treated S. ramavarma as a 'vulnerable species'.

While exploring southern Kerala, the authors collected Syzygium rama-varma in flower and fruit from the Chemunji hills, the type locality in Thiruvananthapuram District, and from Kallar Valley, Pambadumpara, Irumbuthara, and the Kadalar forest regions of the Idukki District. The species is surviving in fair numbers of individuals in these five localities and deserves special attention as they belong to the 'vulnerable category' of IUCN. Since it is hitherto reported only from the Thiruvananthapuram (Kerala), Kanyakumari and Theni districts (Tamil Nadu), the present collection from the Idukki District forms an extended distribution of the species. Since the original description is based on only a few 
specimens, a detailed description with notes and colour photographs presented here will facilitate its identification and, hopefully, will correct the existing confusion with S. munronii.

\section{Syzygium rama-varma (Bourd.) Chithra, 1983 (fig. 2)}

Chithra in Nair \& Henry, Fl. Tamil Nadu Ind., ser. I: Analysis 1: 157. 1983, as "rama-varmae".

Lectotype (designated here): INDIA, Kerala, Chemunji hills, Muthukuzhivayal, $4000 \mathrm{ft}$., s.d., T. F. Bourdillon, s.n. [K! (Barcode No.: 000793892).

Specimens examined: INDIA, Kerala, Thiruvananthapuram Dist. Chemunji hills, 4. Aug 1895, T. F. Bourdillon 563; Ibid, 4000 ft., sin. dat., T.F. Bourdillon 3428 (TBGT!). Ibid, 1200 m., 27 Oct 2012, S. M. Shareef 72498 (TBGT); Idukki, Kallar Valley, 1500 m., 27 Mar 2012, S. M. Shareef \& E. S. Santhosh Kumar 72401 (TBGT); Irumbuthara, 1350 m., 29 Mar 2012, S. M. Shareef \& P. E. Roy 72422 (TBGT); Pambadumpara, 1420 m., 27 Mar 2012, S. M. Shareef 72424 (TBGT); Kadalar, 1180 m., 16 May 2012, S. M. Shareef \& M. V. Krishnaraj 72446 (TBGT).

Trees, $c .15 \mathrm{~m}$ high, $94 \mathrm{~cm}$ girth; bark smooth, greyish-white, blaze brownish; branches and branchlets terete. Leaves opposite; petioles $c .9$ mm long; blades 13.5-25.2 (30) x 4.8-11 cm, coriaceous, narrowly elliptic to elliptic-oblong, cordate basally, acute to acuminate apically with an acumen to $2 \mathrm{~cm}$ long; secondary nerves in 14-22 pairs, $0.3-1.4 \mathrm{~cm}$ apart, finely reticulate and looping at margin; intra-marginal nerve 2-tiered, prominent, raised beneath, depressed above, c. $5 \mathrm{~mm}$ from margin; midrib channeled above and raised beneath. Inflorescence a lateral, rarely terminal or subterminal cyme; peduncles $c .5 \mathrm{~cm}$ long. Flowers solitary to few, $4-5 \mathrm{~cm}$ across; pedicel c. $2.2 \mathrm{~cm}$ long; calyx tube c. $0.5 \times 1 \mathrm{~cm}$, broadly turbinate or campanulate, with 4 , broadly deltoid, membranous lobes $0.6-0.8 \times 1$ $\mathrm{cm}$, rounded to obtuse apically; petals white, $0.8-1.5 \times 1.2-1.5 \mathrm{~cm}$, broadly ovate, caducous, free. Stamens numerous; filaments $0.8-2.2 \mathrm{~cm}$ long, white, filiform. Ovary 2-celled; style $c$. $2.1 \mathrm{~cm}$ long, filiform; stigma acute. Fruit greenish-pink, globose $c .4 \mathrm{~cm}$ long. Seeds 1 or 2.

Flowering \& Fruiting: January - June.
Ecology: Syzygium rama-varma occurs in riparian area of evergreen and semi-evergreen forests between 1180-1500 m. altitudes. The authors observed c. 250 mature individuals of different age groups in the Chemunji hills, Kallar Valley, Irumbuthara, Pambadumpara and Kadalar forest areas in association with Antidesma montanum Blume, Cullenia exarillata A. Robyns, Garcinia pushpangadaniana T. Sabu, N. Mohanan, Krishnaraj \& Shareef, Litsea bourdillonii Gamble, Mesua ferrea L., Palaquium ellipticum (Dalzell) Engl., Syzygium gardneri Thwaites, S. hemisphericum (Walp.) Alston, $S$. munronii etc. Syzygium rama-varma is commonly associated with the last species in all observed habitats and can be easily distinguished by its terete branchlets (vs. quadrangular), narrowly elliptic to ellipticoblong leaves (vs. lanceolate), lateral inflorescence (vs. terminal only) and globose fruits (vs. ovoid).

Young leaves of Syzygium rama-varma are purplish-gray and the ripe fruits are edible. The tree often produces adventitious roots from the main trunk (Fig. 1a.). Because the area of occupancy is estimated to be less than $500 \mathrm{~km}^{2}$ and the number of mature individuals in the population to be less than 250, S. rama-varma now moves from the critically endangered (Gopalan \& Henry, l.c.) to the endangered category of the IUCN (version 2012.1).

Distribution: India: Endemic to the southern Western Ghats, 1180-1500 m., Kerala (Thiruvananthapuram and Idukki Districts) and Tamil Nadu (Kanyakumari and Theni Districts).

\section{Acknowledgements}

We are thankful to the Director (Royal Botanic Gardens, Kew) for allowing us to reproduce the type image of Syzygium rama-varma, P.G. Latha (Director, JNTBGRI) for constant encouragements, and K. R. Sasidharan (FRC) and A. G. Pandurangan (TBGT) for herbarium facilities. Finally we would like to thank J. F. Veldkamp (L) who reviewed an earlier draft of the manuscript.

\section{Literature cited}

Ahmedulla, M. and M. P. Nayar, 1986. Endemic Plants of the Indian Region Vol. 1. Peninsular India, Botanical survey of India, Kolkatta: 108. 
Bourdillon, T. F., 1904. Eugenia rama-varma Bourd., Indian Forester, 30: 147, t. 2.

Brandis, D., 1906. Indian Trees. An account of trees, shrubs and woody climbers, bamboos and palms indigenous or commonly cultivated in the British Indian Empire. A. Constable, London: 318.

Gamble, J. S., 1919. Flora of the Presidency of Madras. Vol. 1. Adlard \& Son Ltd., London: 474.

Gopalan, R. and A. N. Henry, 2000. Endemic plants of India: Camp for the strict endemics of Agasthiyamalai Hills, S.W. Ghats. Bishen Singh Mahendra Pal Singh, Dehradun: 403-407.

McNeill, J., Barrie, F. R., Burdet, H. M., Demoulin, V., Hawksworth, D. L., Marhold, K., Nicolson, D. H., Prado, J., Silva, P. C., Skog, J. E., Wiersema, J. H., and Turland, N. J., (eds.), 2006. International Code of Botanical Nomenclature (Vienna Code) Regnum Vegetabile 146: 1-568.

Nair, N. C. and A. N. Henry, (eds.), 1983. Flora of Tamil Nadu, India, Ser.1: Analysis Vol. 1. Botanical Survey of India, Coimbatore: 157.

Nayar, M. P., 1996. Hotspots of endemic plants of India, Nepal and Bhutan. Tropical Botanic Garden and Research Institute, Palode, Thiruvananthapuram: 197.

Ramesh, B. R. and J. P. Pascal, 1997. Atlas of endemics of the Western Ghats (India). Distribution of tree species in the evergreen and semi-evergreen forests. French Institute, Pondichéry: 319.

Stafleu, F. A. and R. S. Cowan, 1976. Taxonomic Literature 1. Regnum Vegetabile, 94: 305.

IUCN 2012. IUCN Red List of threatened species. Version 2012. 1. 〈www.iucnredlist.org〉. Downloaded on 1 August 2012.
Submitted: 20 May 2013, Accepted: 18 Nov. 2013 Sectional Editor: James L. Reveal

\author{
S. M. Shareef ${ }^{1,3}$, P. E. Roy ${ }^{1}$, E. S. S. Kumar ${ }^{1}$ \\ \& M. V. Krishnaraj ${ }^{1,2}$
}

${ }^{1}$ Jawaharlal Nehru Tropical Botanic Garden and Research Institute, Palode, Thiruvananthapuram 695562 Kerala, India

${ }^{2}$ Postgraduate Department of Botany, Bishop Abraham Memorial College, Thuruthicad, Pathanamthitta, Kerala, India E-mail: smshariftbgri@gmail.com ${ }^{3}$ 


\section{PLATE 6}

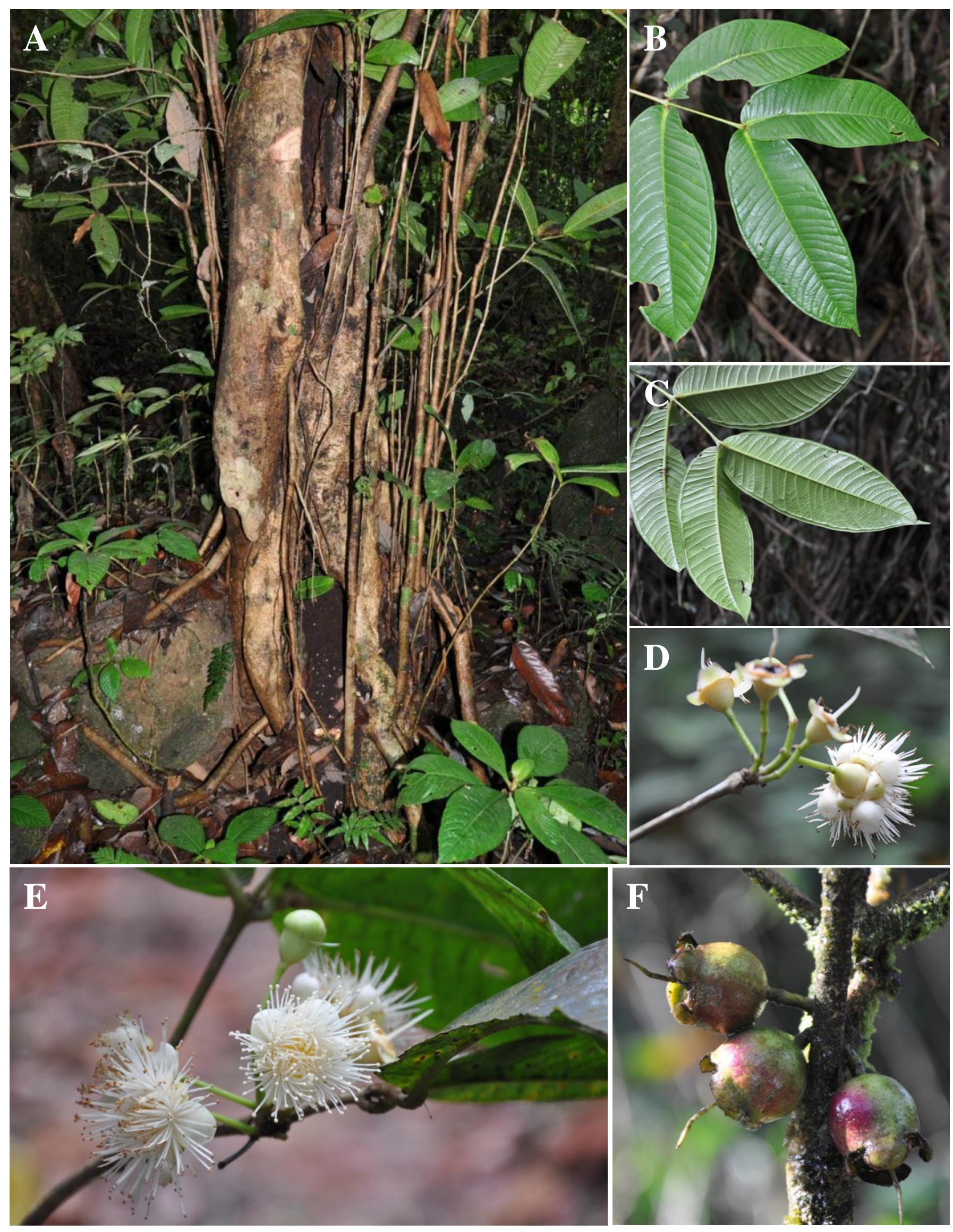

Figure 1: Syzygium rama-varma, A, Habit; B. \& C, leaf- dorsal and ventral view; D. \& E, Inflorescence (terminal and lateral); F, mature fruit 


\section{PLATE 7}
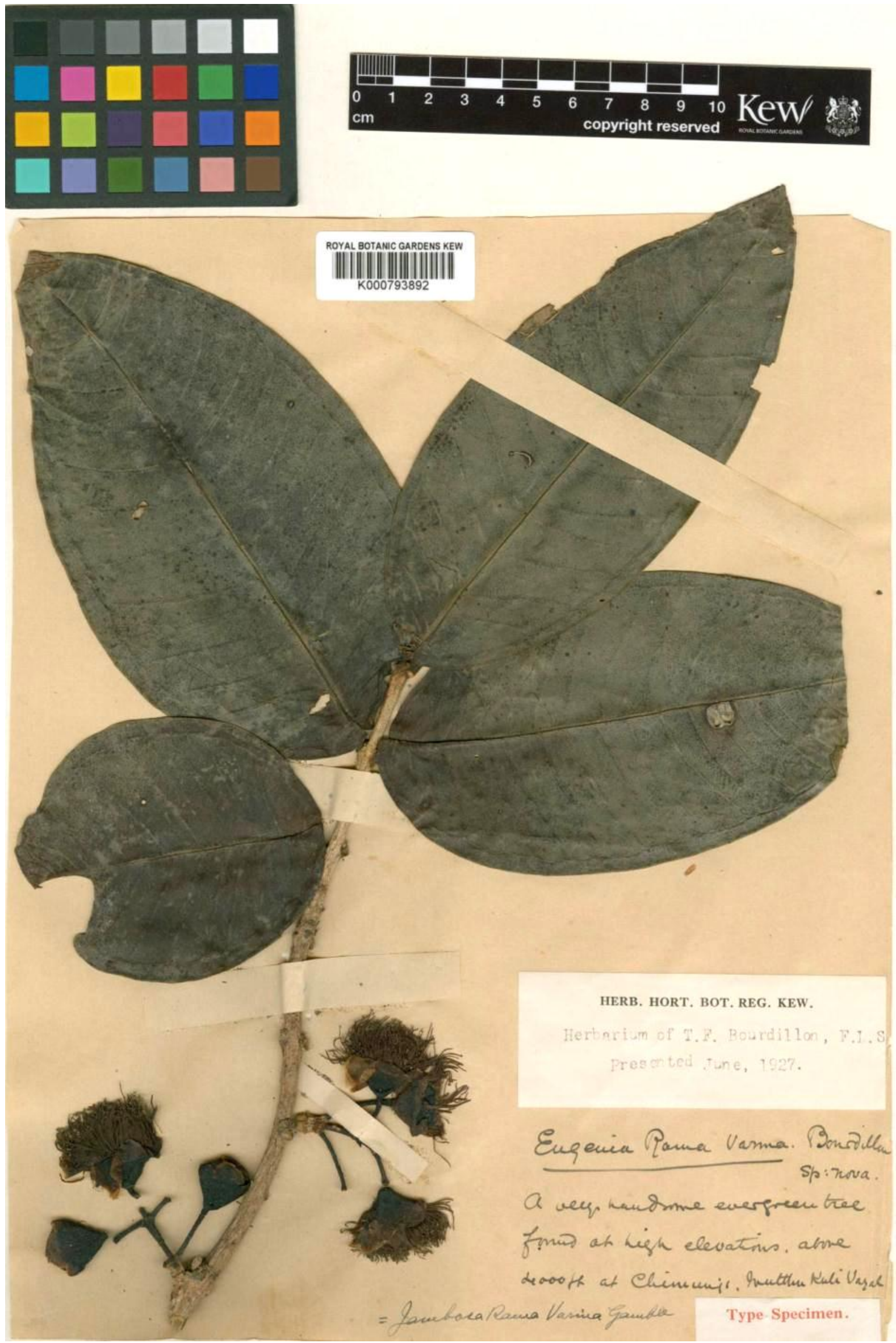

Figure 2: Lectotype of Syzygium rama-varma (K! Barcode No.: $000793892 @$ Royal Botanic Gardens, Kew) 